UC.25

Reporting Date: April 1975 Issued: August 1975

Electron-Beam Welding of 21-6-9 (Cr-Ni-Mn) Stainless Steel: Effect of Machine Parameters on Weldability

by

Hugh Casey 
Printed in the United States of Amorica. Available from National Tochnicel Information Service

US Depariment of Commerce
52B5 Part Royal Road

Springtiold, VA 22151

Price: Printed Copy $\$ 4.00$ Microfiche \$2.25

Thix report was prepsed at an account of work nponsored br the United Silues Governinent. Neither the United States nor the United Scates Esseray Revesreh and Development Ad. miniotration, nar anv of their employnes, nar eny of thair con. traclorc, aubconiractorth or their employent. malto any responsibility for the ece uracy. completenews, or unetulpos of anv information. appartuse, product, or procest diuclored, of repreasnte that ita une would nol ipfringe privalely owned rixhte. 


\title{
ELECTRON-BEAM WELDING OF 21-6-9 (Cr-Ni-Mn) STAINLESS STEEL: EFFECT OF MACHINE PARAMETERS ON WELDABILITY
}

\author{
by
}

\author{
Hugh Casey
}

\begin{abstract}
The high-manganese, nitrogen-strengthened 21-6-9 (Cr-Nj-Mn) austenitic stainless steel has a weldability rating similar to that of more common austenitic stainless steels in terms of cracking, porosity, etc. However, weld pool disruption problems may occur with this alloy that can be related to instability within the molten weld pool. Selection of machine parameters is critical to achieving weld pool quiescence as this report confirms from recent tests.

Test samples came from heats of air-melted, vacuum-arc remelted, and electroslag remelted material. Low- and highvoltage machine parameters are discussed, and effects of parameter variation on weld pool behavior are given. Data relate weld pool behavior to weld fusion-zone geometry. Various weld parameters are recommended for the 21-6-9 alloy, regardless of its source or chemistry.
\end{abstract}

\section{INTRODUCTION}

A recently developed series of nitrogenstrengthened austenitic stainless steels have a yield strength substantially greater than that of other ausıenitic steels such as those typified by the 300 series. These nit rogen-strengthened st eels also retain the austenite stability and corrosion resistance of conventional stainless steels. The austenite stability is obtained by the overall alloy balance, in which the manganese content is particularly important: the higher strength results mainly from the solidsolution strengthening effect of the nitrogen. The increased strength and good hydrogen compatibility of these steels $c \cdot$, important to Energy Research and Development Administration (ERDA) contractors.

Some unusual problems have arisen in electronbeam welding of the nitrogen-strengthened steels. particularly the 21-6-9 ( $\mathrm{Cr}-\mathrm{Ni}-\mathrm{Mn})$ allov. Violent eruptions can occur in the weld pool, causing ejection of molten spatter and, in the extreme case. complete erosion of the top bead. This behavior would seem to be related to the alloy's high nitrogen content. and data exist to support this theory. ${ }^{1}$ However, the weldability of this alloy is extremely: sensitive to weld-parameter variations. The problem may seem analogous to the outgassing effects experienced with rimmed steel welding, for example. hut accepted procedures for obtaining weld pool quiescence when gas evolution is a problem are not applicable to the 21.6-9 steel and may actually increase the problem.

The purpose of this report is to define these parameter effects so as to provide the welding engineer with a useful guide in selecting parameters for a particular application. Detailed theorizing on the causes of the weld pool phenenomon will be covered in other reports by ERDA contractors. including Lus Alamos Scientific Laboratory (LASL). which are to be compiled and issued as cont ributions to the JOWOG 22 program.

The term "weldability" as used here refers only to the defects associated with the weld pool disruption phenomena. The 21-6-9 alloy is apparently no more 
susceptible to cracking. porosity, or other common defects than, for exampla, a $304 \mathrm{~L}$ alloy.

\section{PROCEDURE}

Test material was taken from four heats of 21-6-9 stainless-steel stock within the ERDA facilities. Material descriptions are given in Table I. The specimens were prepared by surface grinding and swabbing with an alcohol-hase solvent immediately hefore welding. All welds were bead on plate to minimize fixturing and the extraneous effects of surface cortaminants, and all welds were autogenous.

The tests were conducted with low- and highvoltage electron-beam equipment. The low-voltage machine was a Sciaky $30-\mathrm{kW}$ unit, and a $250-\mathrm{mA}$ cathode/filament gun combination was used. The high-voltage machine was a Hamilton Standard 7.5 . $\mathrm{kW}$ unit, and an R.to gun with a $0.833-\mathrm{mm}$ hairpin tïlament was used.

Choice of nominal parameters for each system was based on the $\sim 1.5-\mathrm{kW}$ power range (see Table II). Individual parameters were then varied to determine their effects on the weld bead. Because electron- beam welding machine paramelers are interdependent to a great extent, additional tests were made at constant power (varying current and voltage combinations) and constant heat input (compensating for speed variations with appropriate power alterations). Most of the tests were made as linerar weld passes, but circular and rotary welds were also examined. Multipass welds were made to determine whether repeated remelting of the same weld zone produced any variations in pool quiescence.

\section{RESULTS}

Although the four heats of $21-6-9$ stainless steel used in this study produced both good (acceptablet and had (unacceptable) welds under particular weld-parameter conditions, the weldability of the in. dividual heats varied significantly. Figure 1 . which shows five weld passes on the same piece of material. illustrates the steel's high sensitivity to parameter variations. This extreme effect was not reproducible on all of the test material, but a similar trend was noted in all welded samples.

Parameter data were compiled by categorizing weld top-bead appearance. The reference standards

TABLE I

MATERIAL USED FOR WELD TESTS

\begin{tabular}{|c|c|c|c|c|}
\hline $\begin{array}{c}\text { Material Designation: } \\
\text { Supplier: } \\
\text { Heat No.: } \\
\text { Element }\end{array}$ & $\begin{array}{c}\text { No. } 1 \\
\text { Carpenter } \\
\text { VAR } 81162^{\mathrm{a}} \\
(\mathrm{wt} \%)\end{array}$ & $\begin{array}{c}\text { No. } 2 \\
\text { Carpenter } \\
\text { ESR 82289b } \\
(\text { wt } \%)\end{array}$ & $\begin{array}{c}\text { No. 3 } \\
\text { Carlson } \\
\text { AM 490124-2Cc } \\
(\text { wt } \%)\end{array}$ & $\begin{array}{c}\text { No. } 4 \\
\text { Jorgensen } \\
\text { AM536649c } \\
(w 1 \%)\end{array}$ \\
\hline ( 'r & 19.8 & 19.5 & 20.06 & 19.99 \\
\hline $\mathrm{Ni}$ & 7.2 & 7.1 & 6.65 & 6.(1) \\
\hline Mn & 9.7 & 9.7 & 8.96 & 8.7 \\
\hline (' & 0.027 & 0.012 & $(1.0): 3.3$ & (1).0):3:3 \\
\hline$S$ & 0.004 & 0.00 .3 & 0.011 & $(1.012$ \\
\hline$P$ & $<0.04$ & $<0.06$ & 0.019 & 0.019 \\
\hline $\mathrm{Si}$ & 0.50 & 0.30 & 0.22 & 0.70 \\
\hline $\mathbf{N}$ & 0.27 & 0.24 & 0.31 & 0.30 \\
\hline 0 & $\cdots$ & $\cdots$ & (1.0) & $\ldots$ \\
\hline
\end{tabular}


TABLE II

\section{NOMINAL PARAMETERS FOR WELD TESTS}

\section{A. Low-Voltaze (Sciaky) 30-kW Machine}

\begin{tabular}{|c|c|c|}
\hline & Nominal & $\begin{array}{c}\text { Range of } \\
\text { Study }\end{array}$ \\
\hline Accelerating voltage (kV) & 30 & $10-60$ \\
\hline Beam current ( $m A$ ) & 50 & $10-120$ \\
\hline Focus position (mm) & Surface & \pm 50 \\
\hline Weld-travel speed $(\mathrm{mm} / \mathrm{s})$ & 12.7 & $4-60$ \\
\hline Gun/Work distance $(\mathrm{mm})^{a}$ & $150-200$ & $\begin{array}{c}\text { Not } \\
\text { applicable }\end{array}$ \\
\hline
\end{tabular}

\section{B. High-Voltage (Hamilton Standard) $7.5-\mathrm{kW}$ Machine}

\begin{tabular}{rcc} 
Nominal & & Study \\
\cline { 1 - 1 } 125. & & $80-150$ \\
10. & & $5-20$ \\
Surface & & \pm 50 \\
12.7 & & $4-60$ \\
$150-200$ & Not \\
& applicable
\end{tabular}

a Measured from the lower surface of the focus coil housing.

${ }^{b}$ Measured from the heat shield.

NOTE: Vacuum level was not monitored or examined, but was maintained at better than $1 \times$ $10^{-4}$ torr for all weld tests on both machines.

are shown in Fig. 2, and the description of each category is outlined in Table III. Progressive deterioration in the surface of the weld top bead can be seen in Fig. 2. Each macrophotograph exemplifies a weld typical of a particular category, although the width, curvature, etc., may vary greatly within each category.

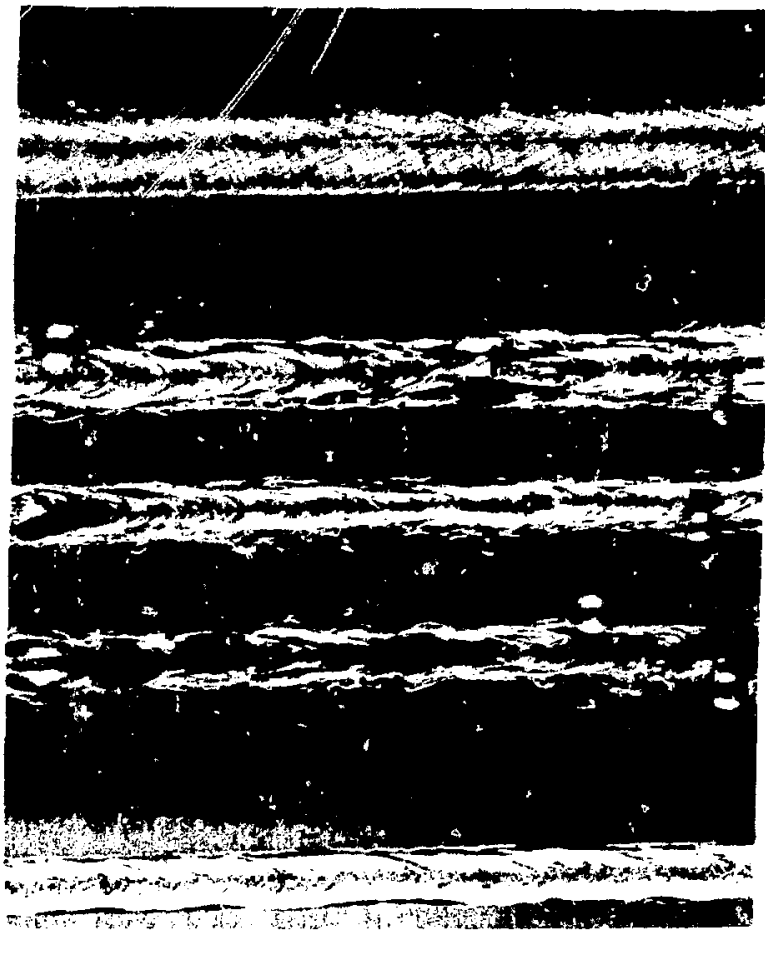

Fig. 1.

Bead-on-plate weld passes on 21-6-9 stainless steel sample. Note high sensitivity to parameter variations. Center weld is sharply focused; adjacent welds are progressively focused above the surface (top) and below the surface (bottom) (3X).

Penetration characteristics naturally are important in weldability studies, and in Figs. 3-5 the penetration characteristics and fusion-zone geometries of the 21-6-9 alloy are compared with a 3C4 stainless-steel standard.

The two alloys show significant differences in penetration characteristics, but the magnitude of these differences diminishes at higher welding speeds (Fig. 6). Only at welding speeds $>25 \mathrm{~mm} / \mathrm{s}$ do the two alloys show similar fusion-zone geometries and penetration efficiencies. The 21-6-9 alloy has high depth/width fusion-zone geometry and shows little evidence of the characteristic electron-beam weld "nail head" (Fig. 7). A reduction in weld speed to $\sim 4 \mathrm{~mm} / \mathrm{s}$ in $21-6-9$ steel does not produce the dramatic change in depth/width ratio evidenced in the 304 samples; this is particularly important in later evaluations of weld-speed effects on weld-pool behavior. 


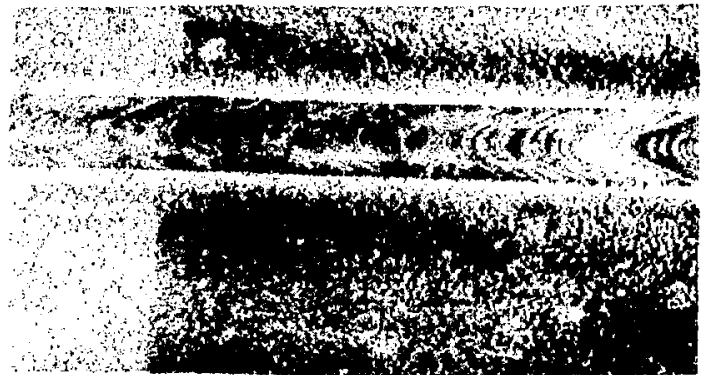

C-1

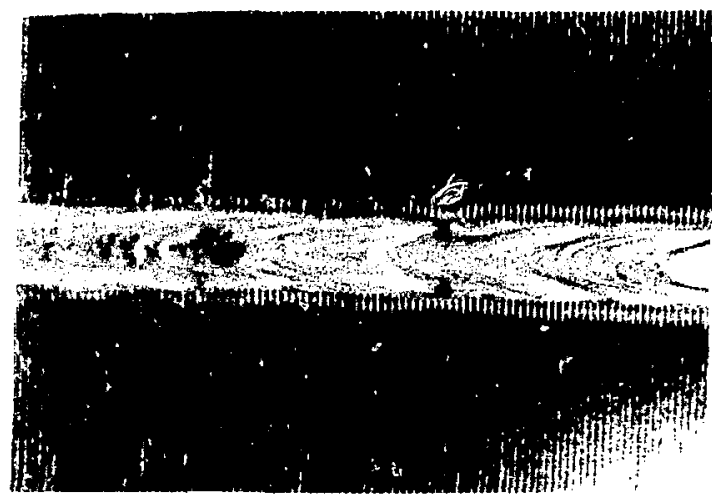

$\mathrm{C}-2$

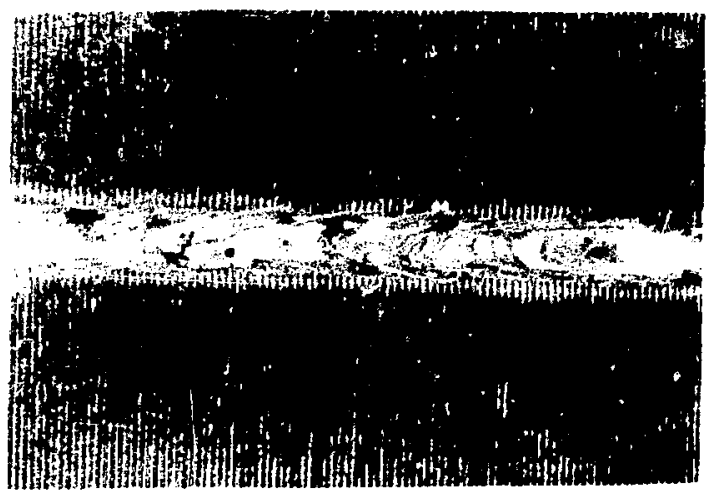

C-3
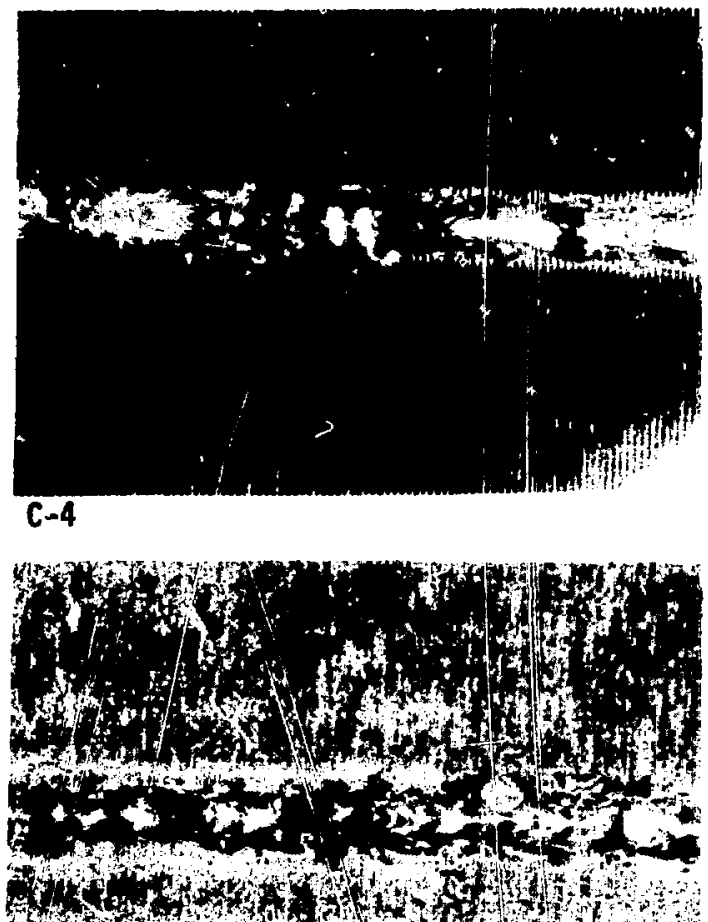

trit $y$

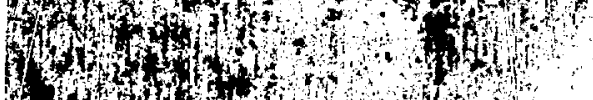

, 1370 th

W 37 tow

C-5

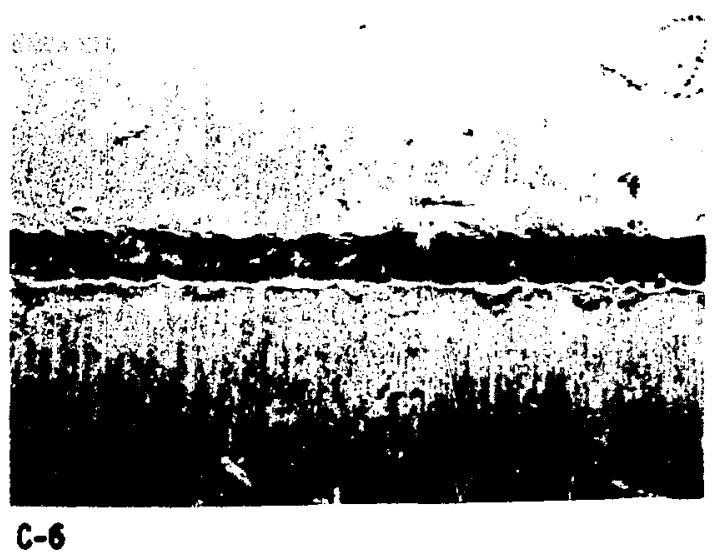

Fig. 2.

Categorizing weld quality by top-bead appearance $(\sim j X)$. 

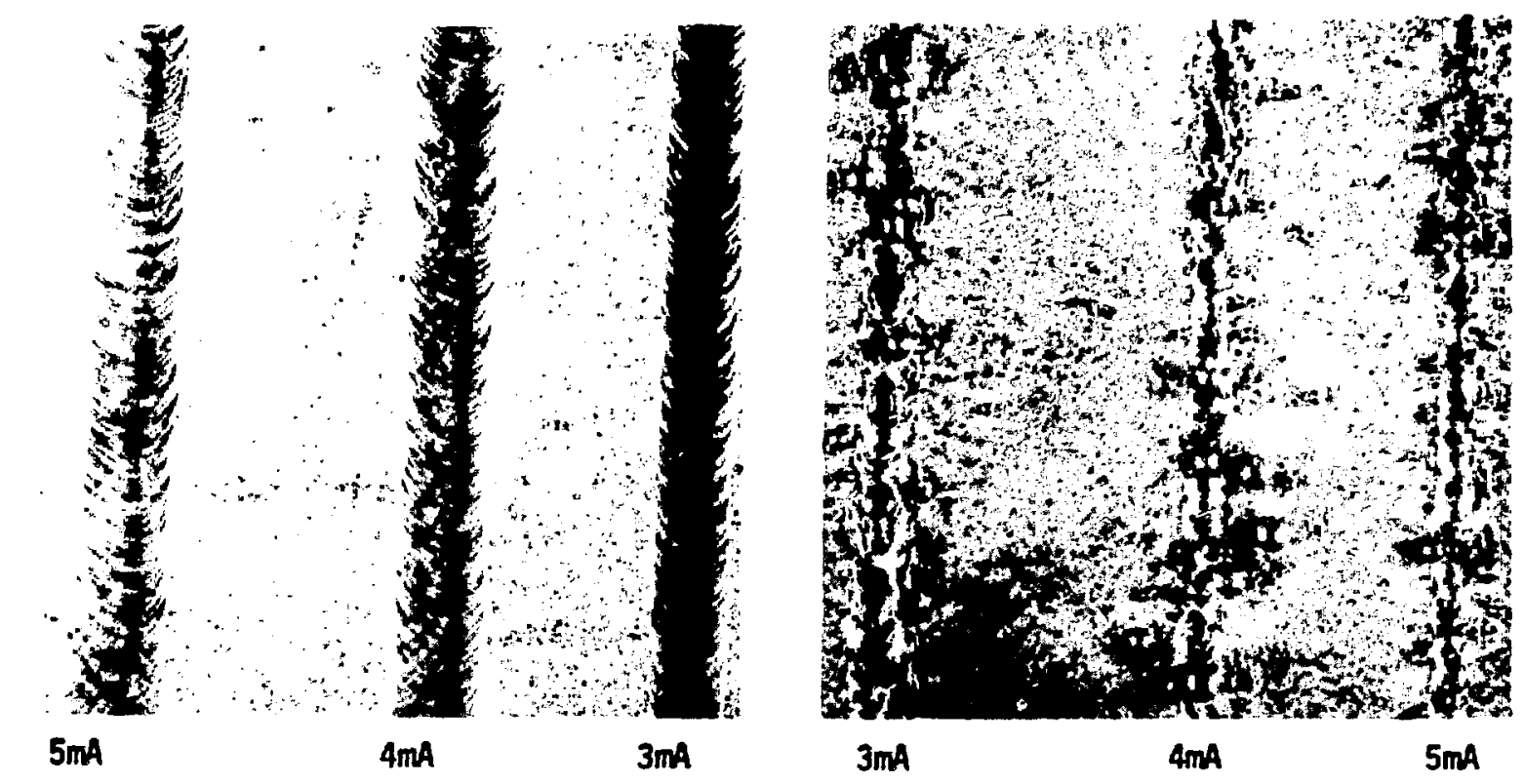

(a) 304 stainless steel

(b) 21-6-9 stainless steel
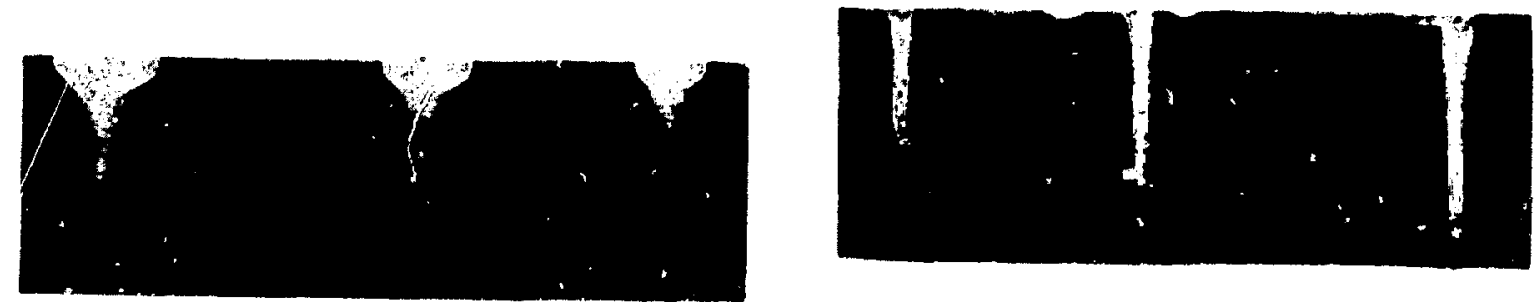

$5 \mathrm{~mA} \quad 4 \mathrm{~mA}$

$3 m A$

$3 m A$

$4 m A$

$5 \mathrm{~mA}$

(c) 304 stainless steel

(d) 21-6-9 stainless steel

Fig. 3.

Comparative weld fusion zones of 304 stainless steel (left) and 21-6-9 stainless steel (right). Surface-focused, $125 . \mathrm{kV}$ weld beam traveling at $4.2 \mathrm{~mm} / \mathrm{s}(5 X)$. 


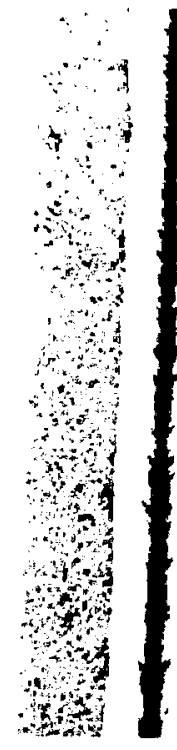

9mA

(a) 304 stainiess steel
$10 \mathrm{~mA}$

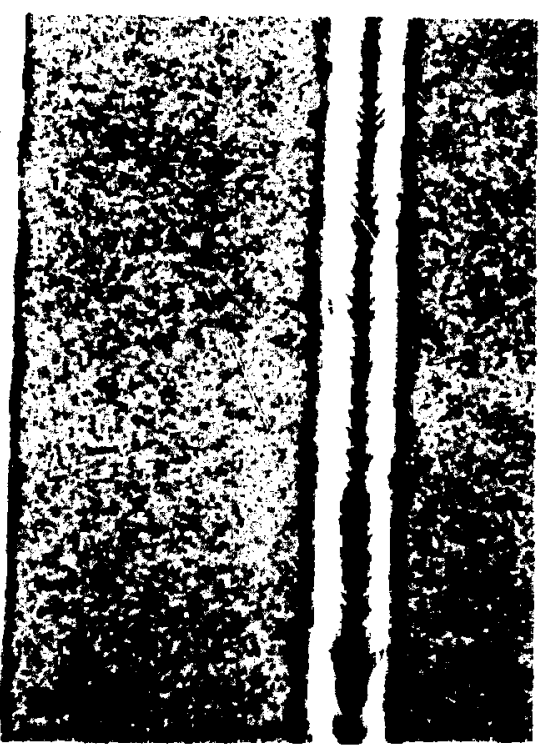

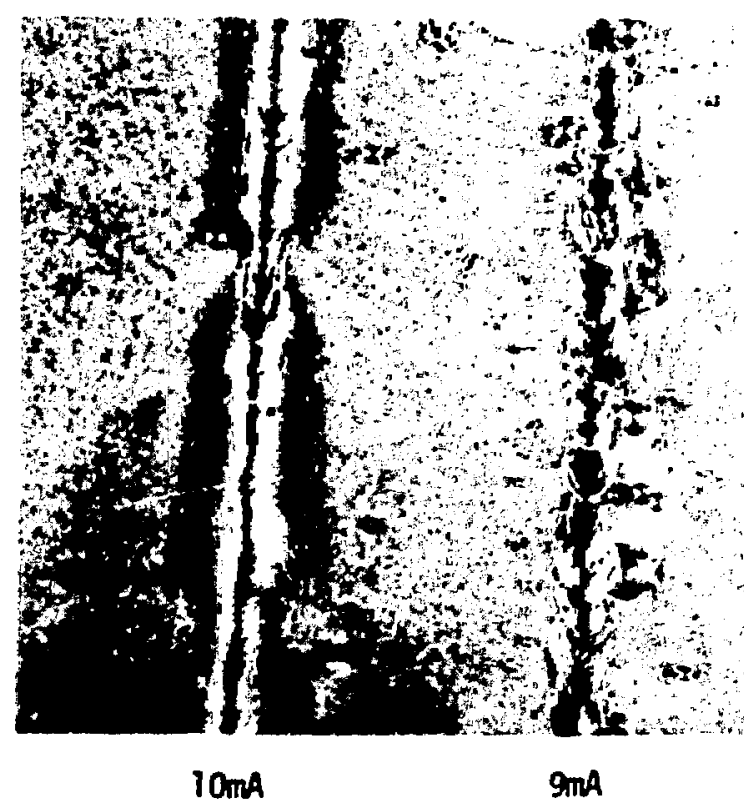

(b) 21-6-9 stainless steel
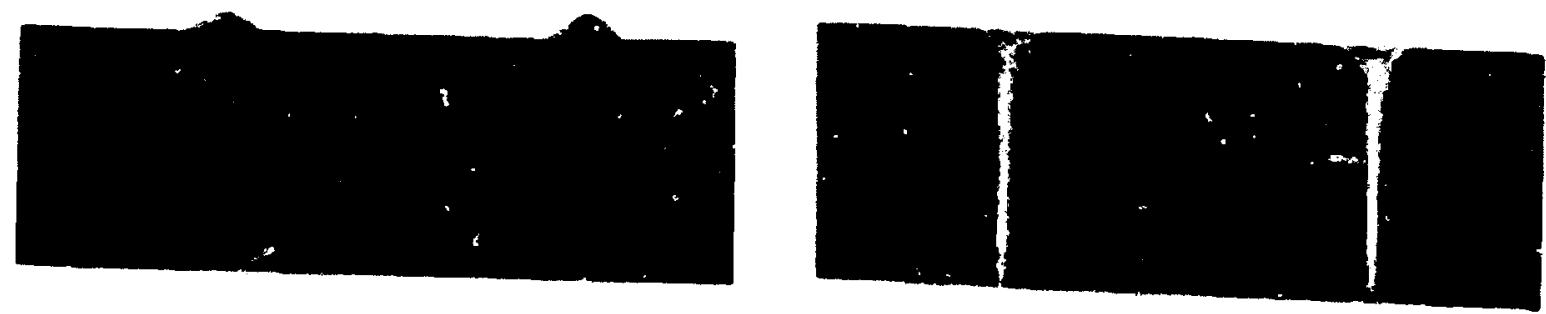

$9 m A$

$10 \mathrm{~mA}$

(c) 304 stainless steel

(d) 21-6-9 stainless steel

Fig. 4.

Comparative weld fusion zones of 304 stainless steel (left) and 2t-6-9 stainless steel (right). Surface-focused, $125 . \mathrm{kV}$ weld beam traveling at $12.7 \mathrm{~mm} / \mathrm{s}(5 \mathrm{X})$. 


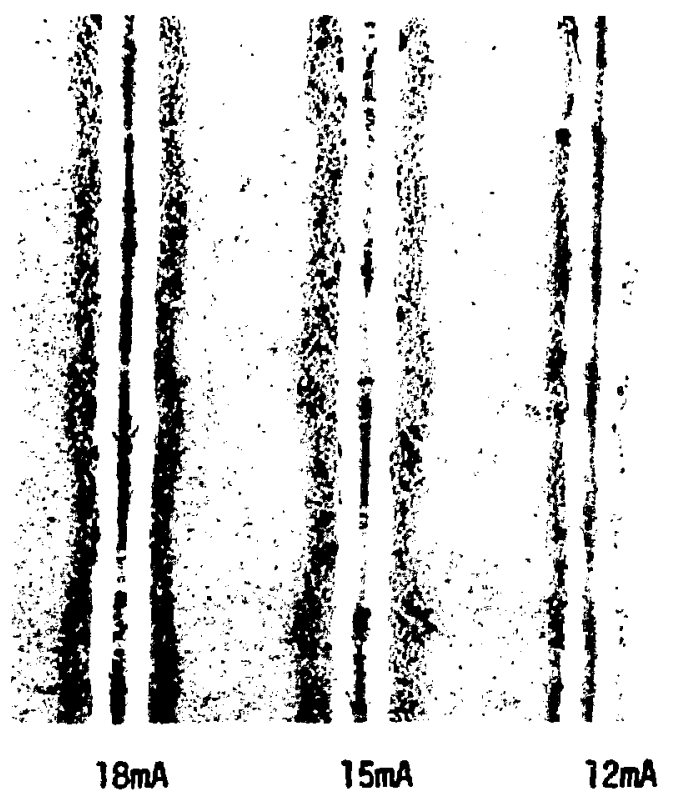

(a) 304 stainiess steel

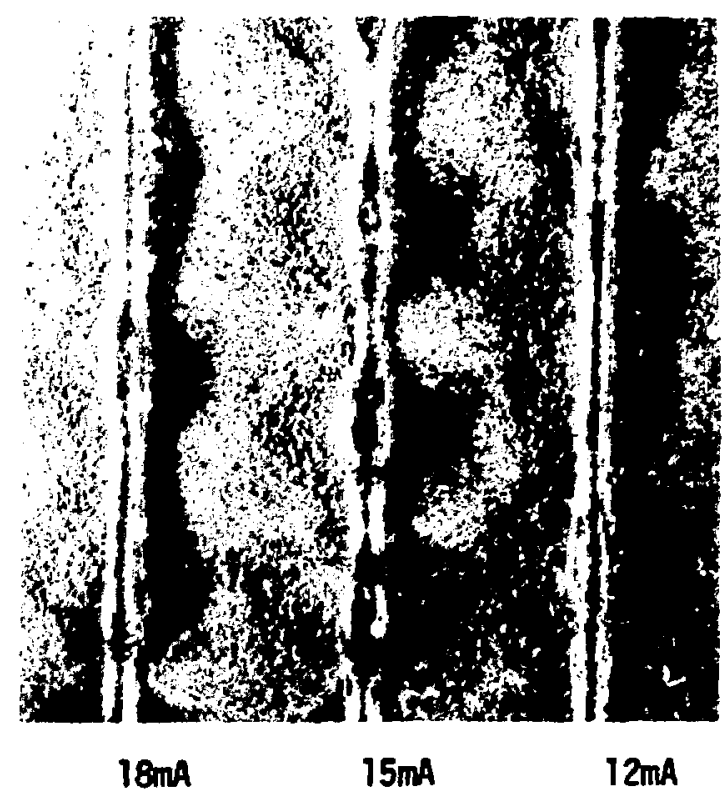

(b) 21-6-9 stainless steel
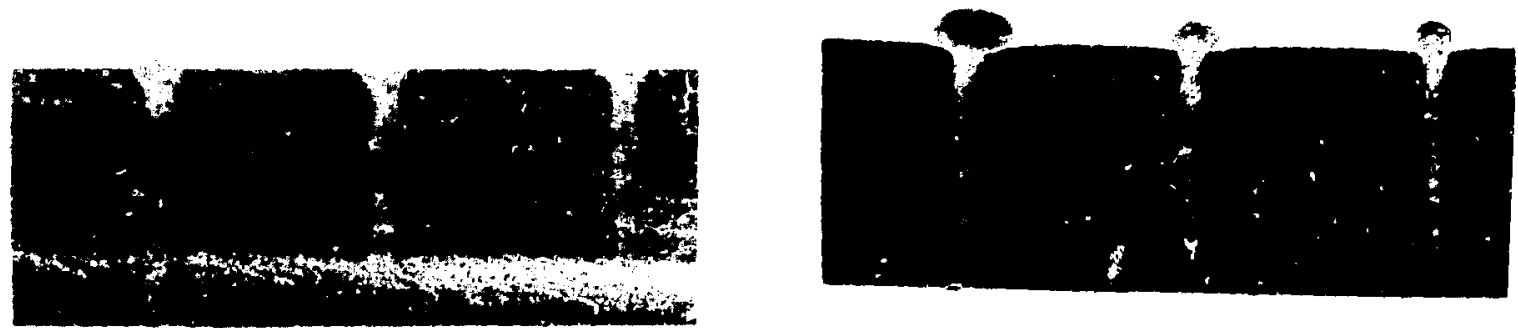

$18 \mathrm{~mA} \quad 15 \mathrm{~mA} \quad 12 \mathrm{~mA}$

(c) 304 stainiess stee 1

(d) 21-6-9 stainiess stee?

Fig. 5.

Comparative weld fusion zones of 304 stainless steel (left) and 21-6.9 stainless steel (right). Surface-focused, $125-\mathrm{k} V$ weld beam traveling at $25.4 \mathrm{~mm} / \mathrm{s}(5 \mathrm{X})$. 
TABLE III

\section{WELD-QUALITY CATEGORIZATION BY TOP-BEAD APPEAKANCE}

Category

1

2

3

4

5

6

\section{Bead Appearance}

Excellent. smooth weld bead. No perturbations or spatter.

Coarsening of solidification lines; slight undulation of weld bead.

Minor weld pool perturbations and slight spatter.

Moderately heavy spatter and cavitation of the weld-bead surface.

Continuous cavitation and severe spatter.

Complete erosion of top-bead surface.
The cavity formed by the electron heam in 21-6-9 is sharply defined, and in most instances there is little melting of the adiacent material. Figure 8 shows a crater formed in a sample when the beam was abruptly terminated. Even on this low depth/width ratio weld zone there is only a trace of melting of the adjacent base metal.

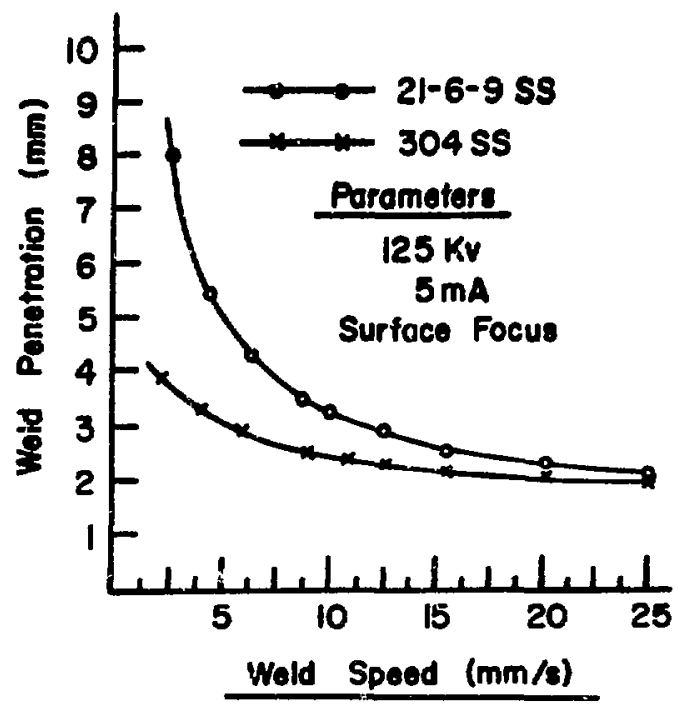

Fig. 6.

Penetration effects when welding 21-6-9 and 304 stainless steels at various speeds.

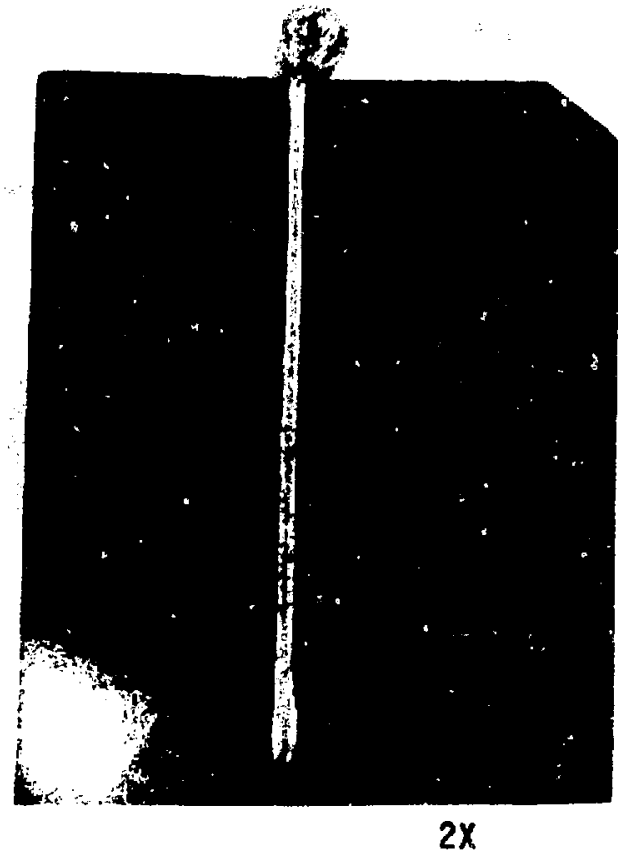

Fig. 7.

Deep (28 $\mathrm{mm}$ ) penetration weld with depth/width ratio $~ 50$; little evidence of "nail head" formation. Parameters are $150 \mathrm{kV}, 45$ $\mathrm{mA}, 12.7 \mathrm{mim} / \mathrm{s}$ travel speed, with surface focus. 


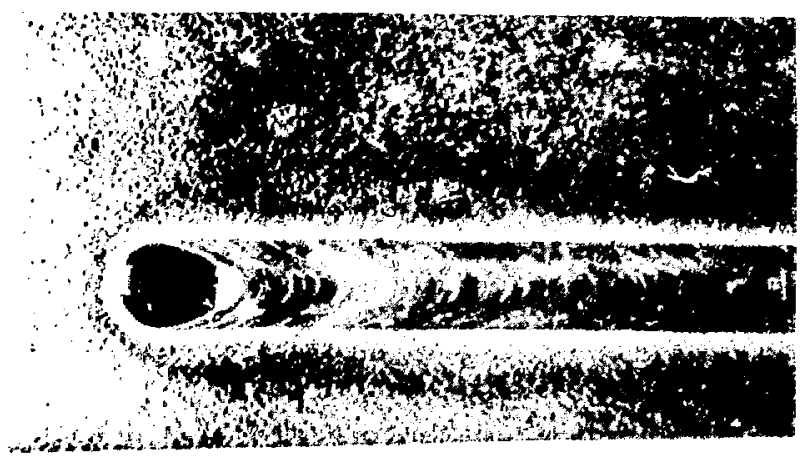

(a) Mar.ro of weld top bead. Mag $3 x$

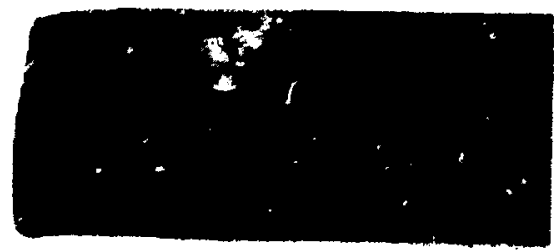

(b) Transverse section to show fusion-zone geometry. Mag $3 X$

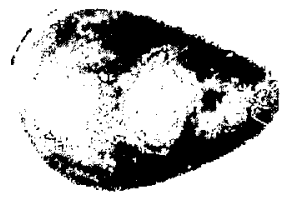

(c) Etched macro to show cavity formation detail. Mag 7X

Fig. 8.

Cavity formation in fusion-zone weid with low (1/1) depth/uidth ratio.

Results of the para:seter study of the 21-6-9 heats are given in Figs. 9-12. Only one parameter at a time was varied over the range under investigation; thus. the weld penetration and the fusion-zone geometry were also changing.

The differences in weldability of the material heats are obvious; however, positive behavior patterns are evident for each of the parameters studied.

- Accelerating Voltage. Results from low- and high-voltage machines show positive improvement in weld quality with increasing accelerating voltage: weld penetration is also increasing. 

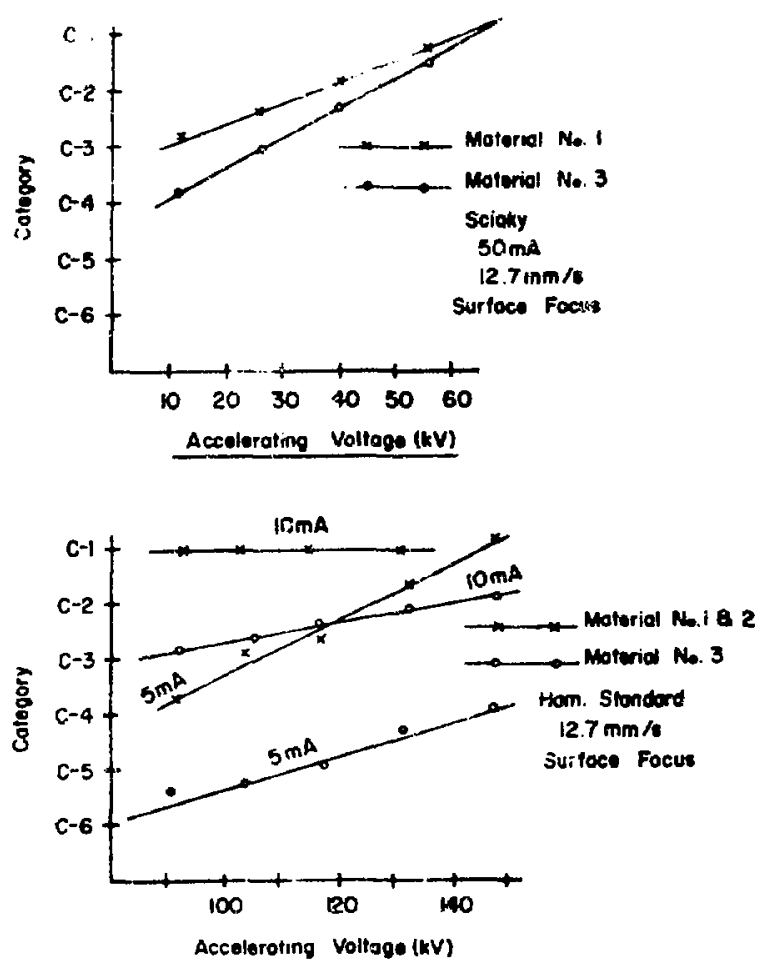

Fig. 9.

Effect of accelerating voltage on weld-bead apperarince at 5 and $10 \mathrm{~mA}$.

- Beam Current. Beam-current increases improve the quality of the weld. Weld penetration is also inreasing, as with accelerating voltage. However. shallow-penetration welds show a sharp depression in the low -volt age curve (Fig. 10). This apparent discrepancy between high-and low-voltage results is ralad to the difference in the fusion-zone fecometries obtained with the different machines. For example, the minimum possible spot size obtained with the ribbon filament (low-voltage) gun is several times larger than that obtained with the hairpin (high-voltage) emitter. The difference is most apparent with low-power, shallow-penetration welds where the minimum fusion-zone widths vary in accordance with the spot-size differences. Thus the difference in weld fusion-zone geometry (depth/width ratio) reaches a maximum with the low-power weld parameters and can account for the shape of the curve at low power levels, as discussed in Sec. IV.

- Focus. The focus effects are exceptionally interesting. Sharply focused or highly defocused beams improve the appearance of welds with both
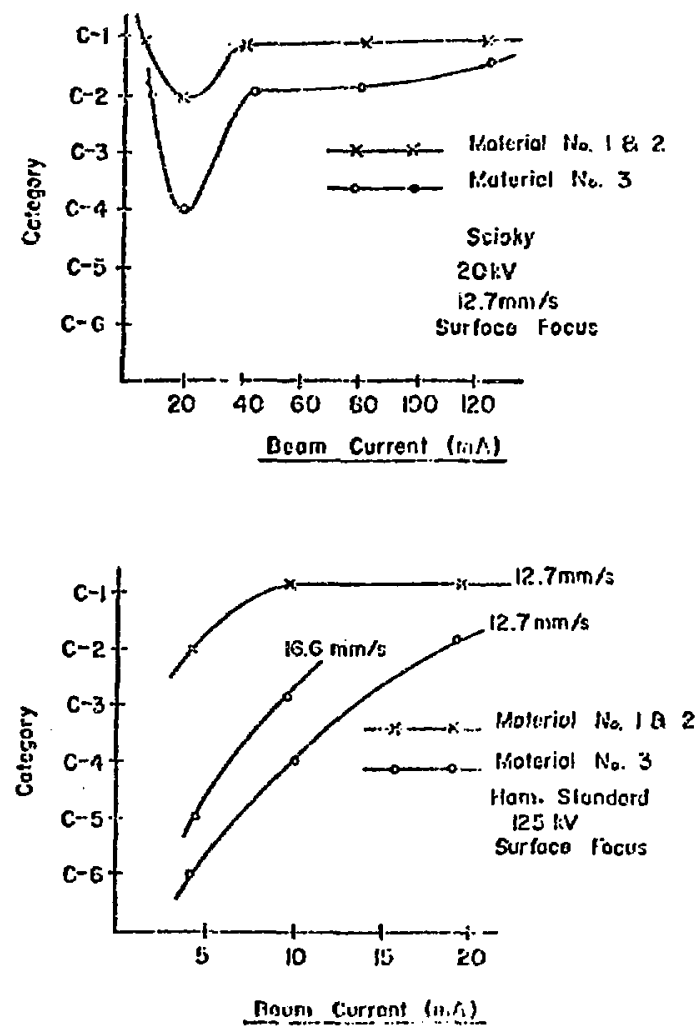

Fig. 10.

Effe't of beain current on weld-bead appearance.

low- and high-voltage systems. The curves for highvoltage dat a show a remarkable degree of symmetry, but differences in the electron optical systems should be considered when comparing the two sets of curves. The hairpin emitter of the telefocus highvoltage gun approximates a point source, but an oval spot. characteristic of the filament image, develops upon defocusing; the ribbon filament of the spherical gun presents a round spot which should exhibit even more symmetry when the beam is defocused. However, the spherical gun is much more sensitive to focus changes than the telefocus gun: hence, minor mechanical misalignments in the cathode/filament region of the low-voltage gun can produce major beam-spot asymmetries when the heam is defocused, as it was in this study. Thus the shape of the curves for the low-voltage data may he significantly influenced by the precision of mechanical alignment within the cathode region of the gun. Both sets of curves indicate that if the beam 

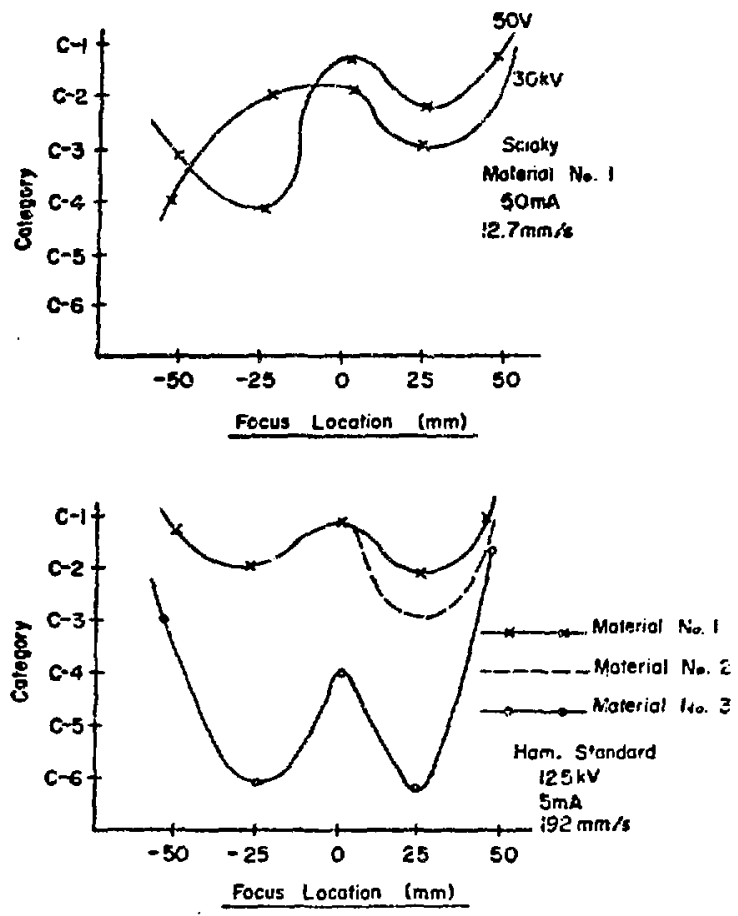

Fig. 11.

Effect of lincation on weld-bead appearance. Nrgative abscissa values are beam locations beloe the surface; positive values are locations aboes the surface.

is defocused at $<50 \mathrm{~mm}$ (within the normal range for most applications\}, welding conditions may be poor in 21-6-9 steel.

- Weld Speed. Weld quality improves substantially with increasing weld speed. Weld penetration is concurrently decreasing. The inferences in the above discussions of accelerating voltage and beam current (that increasing penetration improves weld quality) are apparently contradicted by the effect of increased weld speed and decreasing penetration. However, the response of 21-6-9 steel to weld-speed variations is unique when compared with other austenitic steels. Slow-speed welds in 21-6-9 produce basically unstable, deep, narrow fusion zones, uncharacteristic of the fusion zones of other austenitic steels. One theorizes that increased weld speed provides more stability in the 21-6-9 weld zone because of improved dynamic equilibrium within the weld pool.

The unpredictab!e effects of the focus and weld speed preclude the possibility of establishing a meaningful heat inpui $(\mathrm{kJ} / \mathrm{mm})$ vs weldability

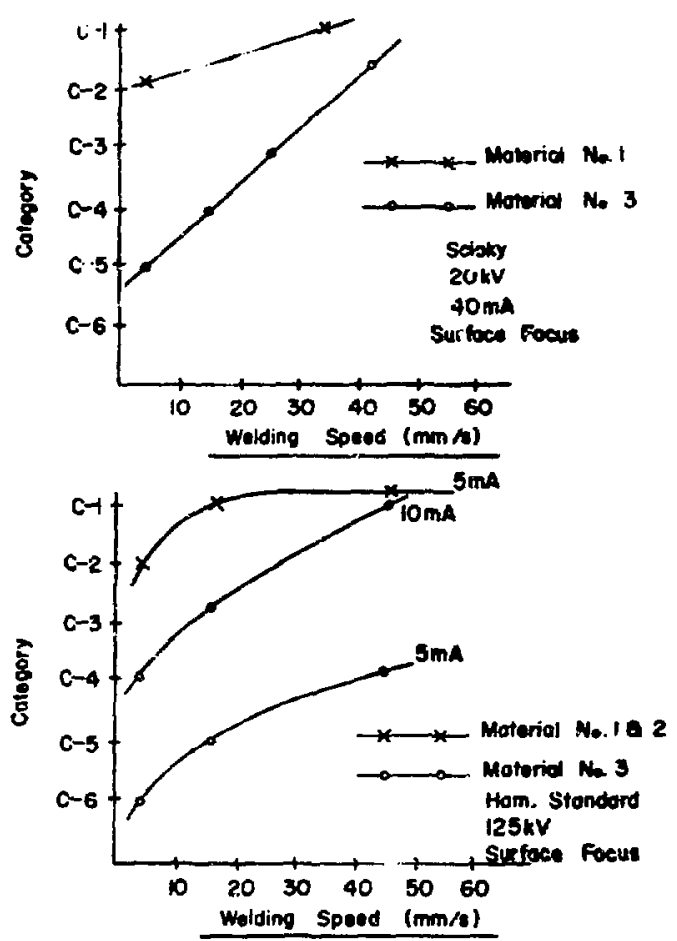

Fig. 12.

Effect of ueld speed on weld-bead appearance.

relationship. The obvious alternative is to compare the fusion-zone geometry with the weld quality. The first attempts to organize these data were unsuccessful hecause weid-speed variations so altered the relationships that the results were meaningless. However, with a constant weld speed of $12.7 \mathrm{~mm} / \mathrm{s}$ (Figs. 13 and 14), reasonably good correlation for the four heats can be established.

The problems evidently occur in the range of $2 / 1$ to $6 / 1 \mathrm{depth} /$ width values, and satisfactory welds can be achieved at either extreme of these values. From a reference weld speed of $12.7 \mathrm{~mm} / \mathrm{s}$. increasing speed will improve the slope of the curves, and decreasing speed will cause the curves to deteriorate. In Fig. 14. for example, Material No. 3 shows an excellent $(\mathrm{C}-1)$ weld at depth/width values of 14 . When the same material is welded at $4.2 \mathrm{~mm} / \mathrm{s}$ with the same depth/width ratio weld, the resulting weld is of C-5 o'dality.

For the final phase of testing, rotary and circular welds were run for comparison with the linear beadon-plate samples. Results were similar to those previously established for linear weld passes. Bar stock. machined to outside diameters of 25.4 to 127 

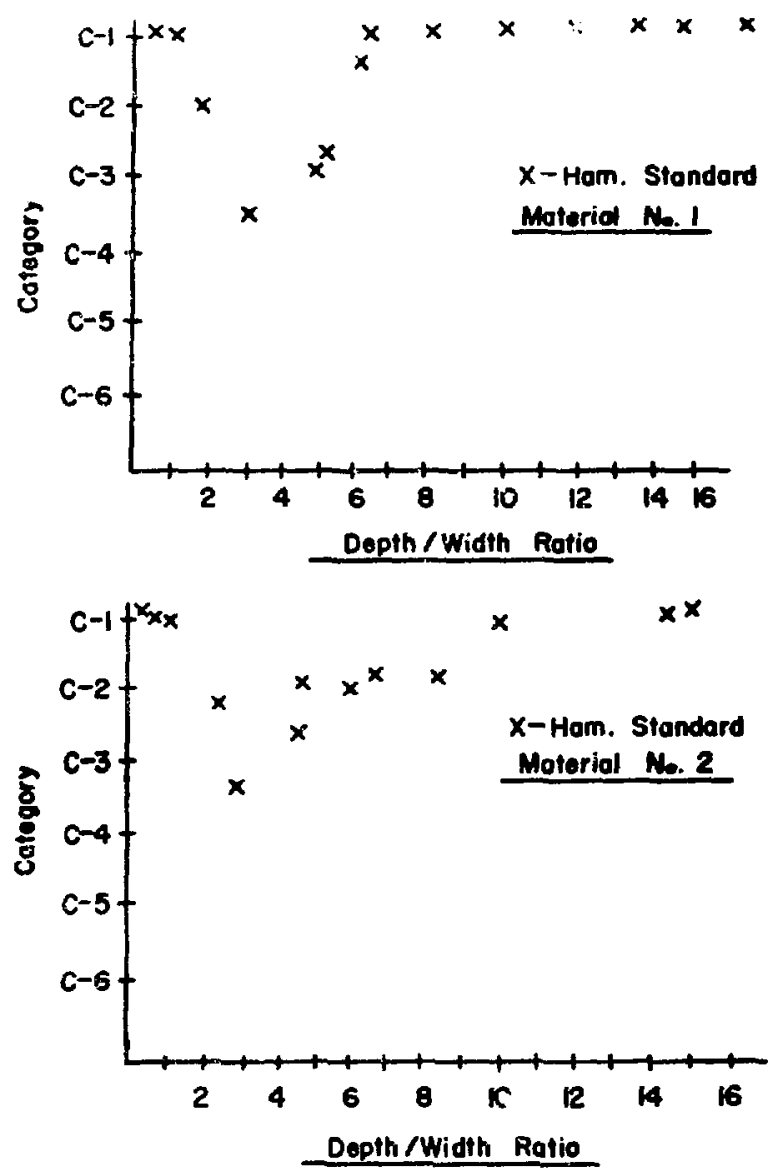

Fig. 13.

('umparison of fusion-zone geometry with weld bred appearance at constant $(12.7 \mathrm{~mm} / \mathrm{s})$ "elding spced. Material Nos. 1 and 2.

mm, was used lor this phase of testing. As many as six passes were made over each linear weld zone, with no observable difference in weld quality.

\section{DISCUSSION}

The main objective of this report is to provide a guide for the selection of weld paraneters for the 21 6-9 alloy, regardless of its chemistry or source. However, the issue is complicated by other factors, such as nonlinearity of focus effects, the high penetration efficiency of the alloy with the subsequent effect on weld speed, and the effects of equipment.
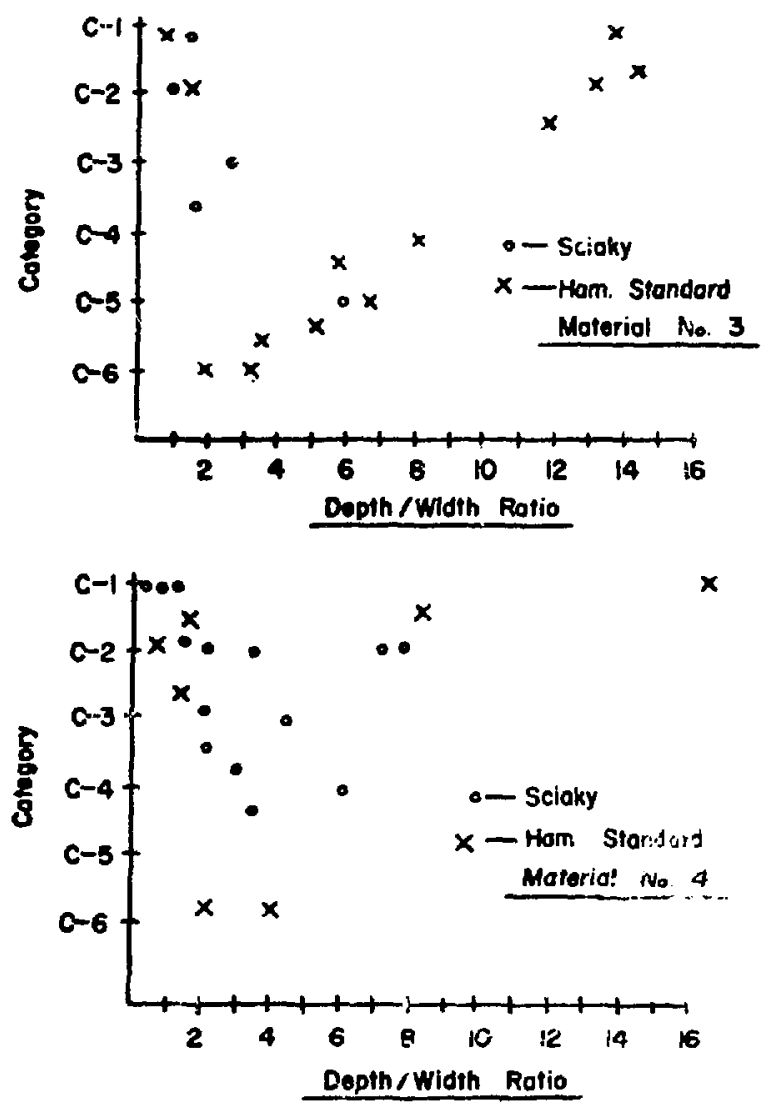

Fig. 14.

Cromparison of fusion-zone geometry with weld bead appearance at constant $(12.7 \mathrm{~mm} / \mathrm{s})$ ueldins speed, Material Nos. 3 and 4.

Rules for parameter selection cannot be made without imposing a number of conditions that define the specific application. It is easier to base parameter selection on the weld geometry obtainable under any particular set of conditions. The weld geometry range in which the problems exist can be determined. If sample material is available, weld geometry vs weldability curves can be generated for the heat of the materiol and the problein range can be defined. In instances where no sample material is available, or when a large number of samples come from unknown heats, the data presented here can be used as a general guide to parameter selection. Distortion or joint-alignment considerations may limit the parameter choice.

The data have already proved useful in the course of routine work at LASL, when welds were made on 
21-6-9 alloy from several heats other than those reported here. Other ERDA contractors have confirmed this data. ${ }^{2-3}$

In the overall investigation of this alloy by ERDA contractors, the ultimate goal is to identify the mechanism and constituents responsible for the weld pool disruption problems and to develop a way to eliminate the problem at the source. It is significant that weld pool disruptions were reproducible, even on the materials of good weldability, designated Nos. 1 and 2 in Table I. If weld pool undulations and minor spatter are indeed caused by the same mechanism that produces the cavitation and cutting action, then it is valid to say that all 216-9 stainless steels exhibit weld pool instability and that the difference between heats is merely one of degree.

As mentioned earlier, reliable data indicate a relationship between weldability and nitrogen content. ${ }^{1}$ However, there are notable exceptions to this relationship, ${ }^{4}$ and it seems logical to suggest an intrinsic contributory factor associated directly with the metal flow characteristics of this alloy. Highspeed photographic techniques ${ }^{5}$ have shown that even in the absence of extraneous effects from nonmetallics, etc., a 21-6-9 stainless-steel weld pool has questionable stability: the molten pool is swelling and undulating, and surface tension can hardly maintain the highly fluid molten metal within the confines of the weld pool. We suggest that the dramatic weld pool disruptions in the 21-6-9 alloy could be caused by minor chemical imbalances having direct effects on either weld-metal fluidity or surface tension. Deep, narrow weld zones produced at higher weld speeds have inherently good stability because of the increased effectiveness of the surface tension. These zones are therefore less subject to weld pool disruption.

A full understanding of this particular welding phenomenon will be achieved only as a result of further investigation into the penetration, heat-flow, and metal-flow characteristics of the alloy during elect ron-beam welding.

\section{CONCLUSIONS}

- The parameter dependency of 21-6-9 stainless steel during electron-beam welding can be related to the genmetry of the fusion zone created. A relationship has been established between the depth/width ratio of the fusion zone and the behavior of the weld pool.
- Weld parameters can be selected on the basis of their effect on the fusion-zone geometry, and acceptable welds san be made on material heats which exhibit weld pool disruptions under standard welding parameters.

- The very high penetration efficiency of this alloy must be considered when predicting the effect of parameter changes on the weld-zone geometry.

- Weld speeds of $<12.7 \mathrm{~mm} / \mathrm{s}$ are not recommended except in cases where the material is of inherently good weldability. Even then, it may be diffirult to make accurate predictions of penetration values.

- Either low- or high-voltage electron-beam welding equipment can be used with equal success. However, with weld penetrations of $<1 \mathrm{~mm}$, substantial differences can be expected in the terhniques required to obtain weld pool quiescence.

- No relationship was detected between the welding mode (linear, rotary, circular) and the weld quality, and multipass weld techniques produced no detectable improvement in weld quality.

- The selection of electron-beam weld parameters will remain restricted by fusion-zone geometry considerations until the material factors responsible for weld pool disruptions can be identified and controlled.

\section{ACKNOWLEDGMENTS}

The author gratefully acknowledges the assistance of Fred F. Flick and Victor Vigil in the preparation and evaluation of the weld test samples.

\section{REFERENCES}

1. J. A. Brooks, "Electron Beam Weldability of High Nitrogen Austenitic Stainless Steel," Sandia Laboratories Livermore report SLL-73-0060 (October 197:3).

2. C. K. Hicken. Sandia Laboratories, Livermore, California, personal communication, June 1975.

3. W. S. Bennett, Dow Chemical USA, Rocky Flats Division, personal communication, June 1975.

4. G. Mara, Lawrence Livermore Laboratory, personal communication, February 26, 1975.

5. R. E. Armstrong, Lawrence Livermore Laboratory, personal communication, February 26 , 1975. 